\title{
A DESIGN-CENTERED LABORATORY CURRICULUM FOR FIRST-YEAR BIOMEDICAL ENGINEERING STUDENTS
}

\author{
Gabrielle Lam \\ School of Biomedical Engineering and Department of Materials Engineering, University of British Columbia, Canada \\ gabrielle.lam@ubc.ca
}

\begin{abstract}
A new first-year biomedical engineering laboratory course was created using a problem-based learning approach. Centered on four semi-structured design projects and experiments, the laboratory course was designed to facilitate meaningful experiential learning. Preliminary analyses of survey results suggest that the semi-structured nature of lab activities is viewed both positively and negatively by students, depending on their perception of preparedness for the project. Its correlation with student performance will be better understood with thorough study of other components of survey results.
\end{abstract}

Keywords: Problem-based learning, experiential learning, biomedical engineering, laboratory course, first-year engineering

\section{INTRODUCTION}

The Biomedical Engineering Laboratory course (BMEG 102) was recently launched in January 2019 as part of the undergraduate program in the newly established School of Biomedical Engineering (SBME) at the University of British Columbia. A core vision of the program is to develop biomedical engineers with critical thinking and practical skills to excel in engineering design, while grounding students in a solid understanding of biology. The first-year laboratory course BMEG 102 was created to bring together both elements - engineering design and biology - through experiential learning opportunities to better prepare students for contributing to a field that interfaces with challenges in engineering and medicine.

Although the value of experiential learning is well recognized across engineering programs, growing evidence suggests that its role in enhancing learning is greatly dependent upon how it is implemented [2,3]. A recent study of introductory physics laboratory courses across three American universities revealed that experiential learning activities did not contribute to improved learning outcome [3]. This may be attributed to overemphasis of complex procedures and little opportunity for reflection, which can cause students to focus on task completion. On the contrary, others have discussed the value of an open-ended problem-based learning approach to enhance student motivation and learning in the engineering laboratory $[1,4]$.

BMEG 102 was structured according to four semistructured design projects or experiments. This problembased approach is expected to facilitate meaningful experiential learning as early as students' first year, which will better equip them for upper-year design courses throughout the program. The course was evaluated according to course assessments, namely lab submissions, which were graded in alignment with course objectives. Furthermore, surveys were administered throughout the course to gather student feedback for each of the four lab modules. Ranking and open-ended survey questions were used to gauge student perception of the value, level of difficulty, and their ability to achieve project objectives.

\section{METHODS}

\subsection{Course Design and Creation}

The course design process began with consulting undergraduate and graduate students in biomedical engineering specializations or student teams at the University of British Columbia. Based on their feedback, the course was created to be centered around four lab modules, each introducing students to a technical stream in the program, including Cellular Bioengineering, Biomaterials and Biomechanics, Biomedical Systems and Signals, and Biomedical Informatics (Figure 1). The lab modules were aligned to weekly lectures, where students were presented with the biomedical engineering-related problem driving each project. Additionally, they explored connections between biology and biomedical technologies. The "biology thread" of the course wove together the biological concepts underlying each lab module, from protein structure to cell membrane potential. 


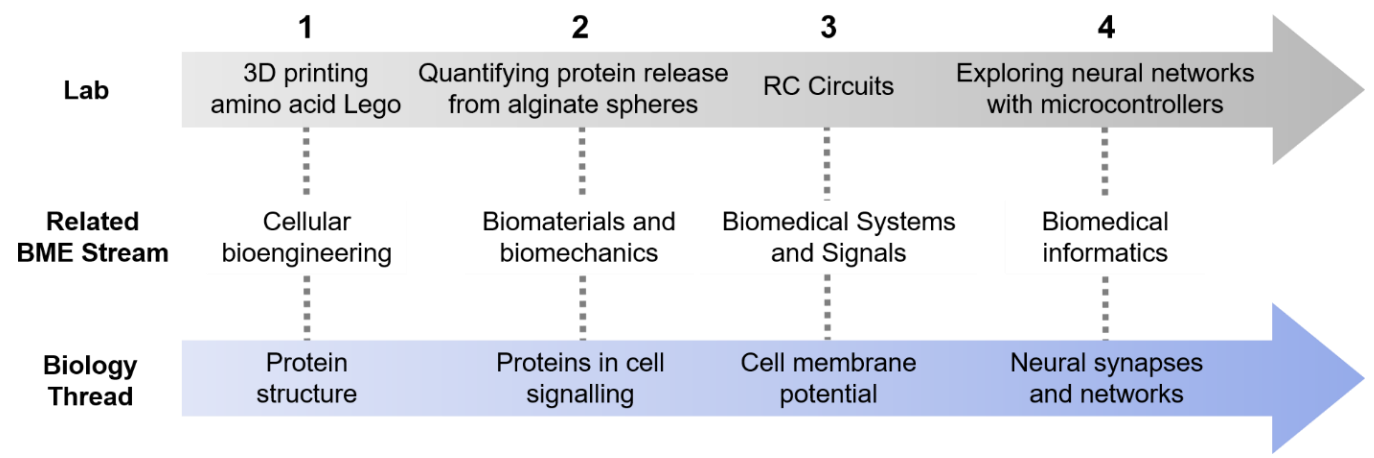

Figure 1. Schematic of the BMEG 102 course structure.

\subsection{Course Evaluation using Student Assessments and Survey Feedback}

Students worked in teams of two or three throughout the course to complete lab module projects. Marking rubrics were created in alignment with course objectives, and team submissions were assessed accordingly. Grades therefore provided a quantitative measure of student performance. The course objectives are as follows:

After completing the course, students should be able to:

- Appreciate the connections between engineering concepts, biological systems and biomedical technologies, as is relevant to the four streams of biomedical engineering

- Understand the relevance of learning topics to current biomedical engineering research

- Develop technical skills in biomedical design and experimentation, including:

- Implementing an iterative approach in engineering design

- Designing an experiment with appropriate controls

- Determining the uncertainty of a measurement and derived value

- Analyzing and graphically representing data

- Using pipettes, balances and electrical measurement devices

- Communicate effectively, professionally and with integrity, through:

- Written and oral presentation of technical information

- Conveying constructive and critical evaluation of peer work

- Working effectively in team settings

To complement data from course assessments, online surveys were created for each lab module. They were developed and administered throughout the course to gauge student engagement, their perception of the value, relevance and level of difficulty of concepts and skills. Survey results would reveal any patterns observed in student performance.

\section{RESULTS}

Lab submissions were assessed according to marking rubrics. The average grades for each lab module submission are presented in Figure 2. Student performance was lowest in Modules 2 and 4, with average grades of $71 \%$ and $70 \%$, respectively.

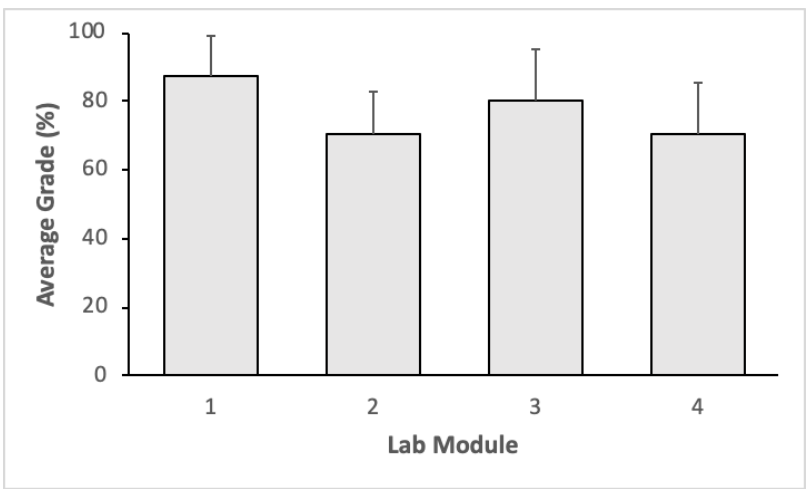

Figure 2. Average grade for each lab module submission (error bars are standard deviation).

Preliminary analyses of lab module surveys provided some insight regarding student performance. Specifically, student comments to two open-ended questions were evaluated. These questions were Question 1) "Something that I gained from this module that I will carry into the rest of my degree" and Question 2) "One or more ways this module could be improved or changed". For each openended question, the number of student responses related to the problem-based approach were quantified (Table 1). 
Table 1. Preliminary analyses of student responses to two open-ended questions from lab module surveys.

\begin{tabular}{|c|c|c|c|}
\hline \multirow{2}{*}{$\begin{array}{c}\text { Lab } \\
\text { Module }\end{array}$} & $\begin{array}{c}\text { Total } \\
\text { number } \\
\text { of student } \\
\text { responses }\end{array}$ & \multicolumn{2}{|c|}{$\begin{array}{c}\text { Number (and percentage) of } \\
\text { responses related to the semi- } \\
\text { structured nature of projects }\end{array}$} \\
\cline { 3 - 4 } & of $)$ & Question 1 & Question 2 \\
\hline 1 & 29 & $5(17)$ & $3(10)$ \\
\hline 2 & 44 & $3(7)$ & $10(23)$ \\
\hline 3 & 24 & $0(0)$ & $4(17)$ \\
\hline 4 & 20 & $0(0)$ & $6(30)$ \\
\hline
\end{tabular}

Examples of student responses to each open-ended survey question are presented in Table 2 .

Table 2. Sample student responses to two open-ended questions from module surveys.

\begin{tabular}{|c|c|c|}
\hline \multirow{2}{*}{$\begin{array}{c}\text { Lab } \\
\text { Module }\end{array}$} & \multicolumn{2}{|c|}{ Sample student responses to: } \\
\hline & Question 1 & Question 2 \\
\hline 1 & $\begin{array}{l}\text { "The process of } \\
\text { iteration, trial and } \\
\text { error; not being afraid } \\
\text { to make mistakes" }\end{array}$ & $\begin{array}{l}\text { "More clear instruction } \\
\text { on what is expected at } \\
\text { the early stages" }\end{array}$ \\
\hline 2 & $\begin{array}{l}\text { "Lab was really } \\
\text { interesting and I } \\
\text { actually liked that it } \\
\text { was challenging, as it } \\
\text { made me spend more } \\
\text { effort into thinking } \\
\text { about the experiment } \\
\text { and subsequently } \\
\text { writing up the } \\
\text { experimental } \\
\text { procedure. It made me } \\
\text { more tenacious in a } \\
\text { way and I hope that I } \\
\text { will be able to apply } \\
\text { this "tenacity" into my } \\
\text { future work." }\end{array}$ & $\begin{array}{l}\text { "While it was valuable } \\
\text { to have an open ended } \\
\text { project, I believe we } \\
\text { were a little unsure of } \\
\text { how to proceed. Some } \\
\text { more guidance or } \\
\text { placing the lab later on } \\
\text { in the course could help } \\
\text { solve that issue." }\end{array}$ \\
\hline 3 & $\begin{array}{l}\text { "I learned basic } \\
\text { techniques for circuit } \\
\text { design and } \\
\text { development. Forced } \\
\text { us to view the cell } \\
\text { membrane as less of a } \\
\text { biological component } \\
\text { and more in terms of } \\
\text { an engineered device." }\end{array}$ & $\begin{array}{l}\text { "[Need] a more detailed } \\
\text { lab manual procedure" }\end{array}$ \\
\hline 4 & $\begin{array}{l}\text { "Programming } \\
\text { microcontrollers to be } \\
\text { able to control various } \\
\text { outputs and interpret } \\
\text { and process various } \\
\text { inputs" }\end{array}$ & $\begin{array}{l}\text { "More time or } \\
\text { background knowledge } \\
\text { regarding the neural } \\
\text { network would have } \\
\text { been helpful. More time } \\
\text { to study and explore } \\
\text { what the code written } \\
\text { actually does." }\end{array}$ \\
\hline
\end{tabular}

\section{DISCUSSION}

Preliminary analyses of student responses to two openended questions from lab module surveys provided some insight regarding trends in their performance throughout the course. Lab modules with lowest student performance (modules 2 and 4) were associated with greatest percentages of negative student comments related to the semi-structured nature of projects. For lab module 2, for example, written responses to survey Question 2 ("One or more ways this module could be improved or changed") mainly pertained to students' sense of unpreparedness or of being overwhelmed by the experimental design task. This feedback suggests that there is need for strategies to better prepare students prior to the project. This could be accomplished through a series of pre-lab assignments, team-based quizzes, and/or by implementing staged lab activities. The latter solution would involve segmenting the project into smaller design activities, which would culminate into a larger design project. Unlike comments about lab module 2, those associated with lab module 4 were predominantly related to time constraints and students' lack of background knowledge. This feedback will be used to modify the lab module 4 content for future years, including scaling down the scope of the lab project, and incorporating more background information in lecture and pre-lab materials.

Interestingly, lab module 1 was associated with highest student performance and highest frequency of positive comments related to the semi-structured nature of the project (Question 1, 17\%). In these positive comments, students expressed an appreciation for the autonomy to create their own designs, to iterate their designs, and to learn from their mistakes in this iterative process. In addition, this project was also associated with a low frequency of negative comments (Question 2) related to the semi-structured nature of the project, as well as comments related to students' sense of unpreparedness or of being overwhelmed. A cursory examination of survey responses suggests that the semi-structured approach may be seen positively by students when they feel well equipped with the necessary skills and knowledge for the design task. Taken together, new strategies and teaching materials may be developed in the future to better prepare students for more challenging lab activities.

Ultimately, better understanding of the impact of a problem-based approach on student learning would require more thorough analyses of other aspects captured in lab module surveys. Data that has yet to be analyzed include student responses to value-ranking questions that assessed the level of difficulty of activities, and students' perceived achievement of module-specific learning objectives. In addition, students wrote a reflection piece on the three most important skills or qualities of a biomedical engineer, as part of their final project. In this assignment, they were also tasked to discuss how their first-year academic program 
had helped or hampered their development of these key skills. Qualitative analysis of written reflections will be useful as we devise strategies to restructure lab projects with better alignment with course learning objectives. Going forward, these results will be considered collectively to inform us of avenues to improve the course for future years.

\section{Acknowledgements}

I would like to thank Drs. Karen Cheung, Peter Cripton, Jon Nakane, Pete Ostafichuk, Peter Zandstra, as well as staff at the Center for Teaching, Learning and Technology (CTLT) for their support and advice. I also thank the graduate and undergraduate students who offered their time to provide thorough feedback.

\section{References}

[1] Chyi-Shyong Lee, Juing-Huei Su, Kuo-En Lin, Jia-Hao Chang, and Gu-Hong Lin, "A project-based laboratory for learning embedded system design with industry support," IEEE Trans. Edu., vol. 53, no. 2, pp. 173181, 2010.

[2] Lyle D. Feisel and Alberta J. Rosa, "The Role of the Laboratory in Undergraduate Engineering Education," J. Eng. Edu., vol. 94, no. 1, p 121-130, 2005.

[3] Natasha G. Holmes and Carl E. Wieman, "Introductory physics labs: We can do better," Physics Today, vol. 71, no. 1, pp. 38-45, 2018.

[4] Rui H. Chu, Dylan D. Lu and S. Sathiakumar, "Projectbased lab teaching for power electronics and drives," IEEE Trans. Edu., vol. 51, no. 1, pp. 108-113, 2008. 